\title{
Too Generous and Committed: Hullabaloos over Nigerian Foreign Policy Objectives
}

\author{
Muritala Dauda $^{1 *}$, Mohammad Zaki Ahmad ${ }^{1}$, Mohammad Faisol Keling ${ }^{1}$ \\ ${ }^{1}$ School of International Studies, College of Law, Government and International Studies (COLGIS), \\ Universiti Utara Malaysia (UUM), Sintok, MALAYSIA \\ *Corresponding Author
}

DOI: https://doi.org/10.30880/jts.2021.12.02.004

Received 06 September 2020; Accepted 29 October 2020; Available online 12 January 2021

\begin{abstract}
Nigeria's afrocentric foreign policy has in no small measure benefited African continent. This has assisted Nigeria tremendously to have played a leading role towards ensuring peace, stability, cooperation and development in the African continent. The study examines the hullabaloos surrounding the too generous and committed nature of Nigerian foreign policy which has canvassed for varieties of opinions on the need for the country to adjust her foreign policy objectives. The study indicates that if there is a need for Nigeria to adjust her foreign policy objectives towards Africa, it should be more favourable and not the other way round due to numerous unforeseen benefits. The study adopts role theory to describe the position and responsibility shouldered by Nigeria in Africa. As against the position opined by antagonists on the amendment of Nigerian foreign policy's objectives, the theory explains that some benefits are either tangible or intangible forms. This study is qualitative that adopts both primary and secondary sources of data. Twelve (12) respondents were interviewed from various Nigerian government parastatals and higher institutions of learning. Data gotten from the interview was analysed thematically with the aid of Nvivo. The secondary data source was through books, journal articles, newspapers and policy documents.
\end{abstract}

Keywords: Nigeria, foreign policy, afrocentric, Africa, benefits

\section{Introduction}

The Nigerian foreign policy has been consistently Afrocentric since the country's independence in 1960. This has assisted Nigerian leaders to have successfully impacted positively towards numerous developmental projects, peace meetings and cooperation in many African countries. Nigerian leaders have often focused their attention towards ensuring the Principle of the country's foreign policy with strong emphasis on economic development, political cooperation and peacefully settlement of disputes within the continent.

The afrocentric nature of Nigerian foreign policy has accorded the country a great role during both regional and global decision making process. As argued by Levy (2013), the decision-making process at a governmental level can be considerably influenced by the leadership personality, especially when a country's foreign policy orientation and objective are taken into account.Several scholars shared similar consensus that it is very likely that the Nigerian leaders, either from the military or civilian government would always adopt the "notion of four concentric circles of National Interest" (Gambari, 1989, p.2; Adebajo, 2008,p.7; Gambari, 2017, p.12). The first circle, which is regarded as the innermost circle, relates to Nigeria's security and the welfare of its people. This also extends to the preservation of spirit of good neighbourliness with Nigeria's immediate neighbours such as Benin Republic, Chad, Chameroon and Niger. The second interest in on Nigeria's relations with its West African neighbours or popularly known as the ECOWAS subregion. The third circle focuses on Nigeria's commitment to the African continent. 
Lastly, the concern is on the entire world through Nigeria's membership to the organization or institutions outside Africa. As earlier mentioned, Nigerian leaders whether from the civilian administration or the military government has its foreign policy direction which is based on the above-mentioned four concentric circles. The principles of Nigerian foreign policy, particularly the four concentric circles have been the tradition under which every administration in Nigeria has observably complied.

However, studies such as Ashiru (2014), Ota and Ecoma (2015), Oni and Taiwo (2016), Dauda and Ameen (2017) among others, have indicated that Nigeria's positive gesture to other African countries has not been adequately reciprocated by some of its beneficiaries. Rather the benefactor (Nigeria) should be thinking of how best to utilize its resources and be appreciated. Therefore, it is against this backdrop that the study is examine the hullabaloos over the too generous and committed of the Nigerian foreign policy.

\section{Method and Theoretical Framework}

The study utilizes literature related to international relations with special focus on Nigerian foreign policy. The research is qualitative in nature that makes use of both primary and secondary sources of data. The focus of the primary source of data include the professional views granted by experts in the field of International Relations and Foreign Policies, while the secondary data is generated from books, journal articles, bulletins, policy documents, newspapers among others.

The study adopts Role theory to examine the hullabaloos surrounding the assertion of "too generous and committed" nature of Nigerian foreign policy. Role theory is viewed as "any set of behaviors that has a socially agreed-upon function and an accepted code of norms" (Biddle, Biddle and Thomas as cited in Newman and Newman, 1995). The theory believes that as people assume a new role or responsibility, they adjust their behavior in order to conform to observers' expectations. Meaning that, role is mostly given to change people's behaviors or attitudes. Although, changes in human behavior could be either positive or negative but depends mostly on the nature of role that is assumed and the context in which it is assumed. As suggested by Wang and Zhang (2016) that in animal-assisted intervention for example, any program that provides individuals with an opportunity to train or care for animals allows the person to assume the role of teacher or caretaker.

As suggested by the theory that new role or responsibility assumes by an actor, (particularly in the international arena), affects or changes the behavior of that actor. Nigeria as popularly referred to as the giant of Africa has assumed responsibilities in Africa which has directly or indirectly contributed to peace and stability that many African countries are enjoying both at their State/local and regional levels. Responsibilities shouldered by Nigeria through her big brother role in Africa have made the country to have successfully contributed to series of development, cooperation, peace-talks and meetings among African states. The timely intervention of Nigeria to many issues in Africa has convincingly prevented many States in the continent from witnessing another genocide. The theory therefore, best explain the needs for Nigeria's foreign policy objectives to be adjusted in order to benefit African continent more for the former to reap abundant benefits.

\section{Adjustment of Nigerian Foreign Policy's Objectives}

Afrocentric policy has significantly influenced Nigeria's foreign policy orientation to play a more active role in Africa, particularly in expediting the transformation of the OAU to the AU. Nonetheless, beyond the role played by Nigeria during this transformation process, several scholars are of the opinion that the country should have pursued greater flexibility to continue and even expand the level and scope of its kind gesture and assistance to African nations for its own future benefit. Adjustment in the Nigeria's foreign policy objectives and approach could further enhance the expansion of the country's geo-political influence in the African continent.

There are a number of opinions calling for Nigeria to adjust its foreign policy's objectives towards the African continent. The first category of opinion as argued by Ashiru (2014), Ota and Ecoma (2015), Oni and Taiwo (2016), Dauda and Ameen (2017) premised on the proposition that Nigeria should restrain or totally discard its good deeds to Africa as some of the recipient countries did not reciprocate to such gesture. The position of antagonist regarding Nigeria's favour to other countries was equally stressed by informant UniAbuja:

The people that believed Nigeria should discard or reduce its role, believing that the country is doing too much in Africa. They are bringing their own points on the fact that Nigeria is facing some challenges at home economic challenges, we are in recession, we have security challenges, the Boko Haram, the herdsmen and the farmers, multiple social crises. we are having our own challenges and why must we be facing these and still going out there to say we are the champion of Africa, we are front-liners in Africa and we are still holding with passion our Afro-centric policy and posture. So, the era of that has gone, we have to look inward and address issues, the money we are spending there should be spent on our people, our security personnel should be utilized here (Informant UniAbuja, personal communication, September 9, 2017). 
The aforementioned arguments are parts of the positions of the antagonists who are advocating for Nigeria to adjust the country's foreign policy by reducing its positive input or contribution to other country. Believing that such contribution, including monetary assistance, can be rather used to assist its own people and domestic industry rather than assisting those that did not show gratitude to Nigeria.

Nevertheless, the protagonists group was of the opinion that Nigeria should not quantify her benefits to Africa or other countries in terms of cost benefits analysis (Oni \& Taiwo, 2016; Folarin, 2013). This is because there are some intangible benefits coming to Nigeria from other countries that cannot be quantified. The view of the protagonists towards Nigerian foreign policy was equally emphasized by informant Unilorin:

If one looks at the foreign policy on the basis of cost benefit analysis one will get it wrong especially when it comes to relating with ones' neighbours or relating with ones' region and if one is assisting other African countries because one is more endowed than others that is a natural course of action. While one is not under any other obligation to do it, it is strategically important that one do it, because if not, during your time of needs nobody will rise up for you. And there will be always the time of need. If people within your region do not see you in a favourable light, you do not construct a positive image of yourself within your immediate environment, it is not in the interest of your strategic and security interest (Informant Unilorin, personal communication, August 28, 2017).

Therefore, the two groups have their own justifications on whether Nigeria should continue its good gesture of rendering financial and technical assistance to other African countries. On the other hands, many scholars suggested that instead of Nigeria reducing her kind gestures to other African States, as suggested by the antagonist group, the country should do more in order to achieve its foreign policy's objectives qualitatively. Thus, Fig. 1 below are the underlying reasons of the need for Nigeria's foreign policy to do more to other countries particularly the African countries. These reasons include citizen diplomacy, global decision-making, economic reason, Nigeria's external image, leadership role, national interest, security factor, unity and cooperation.

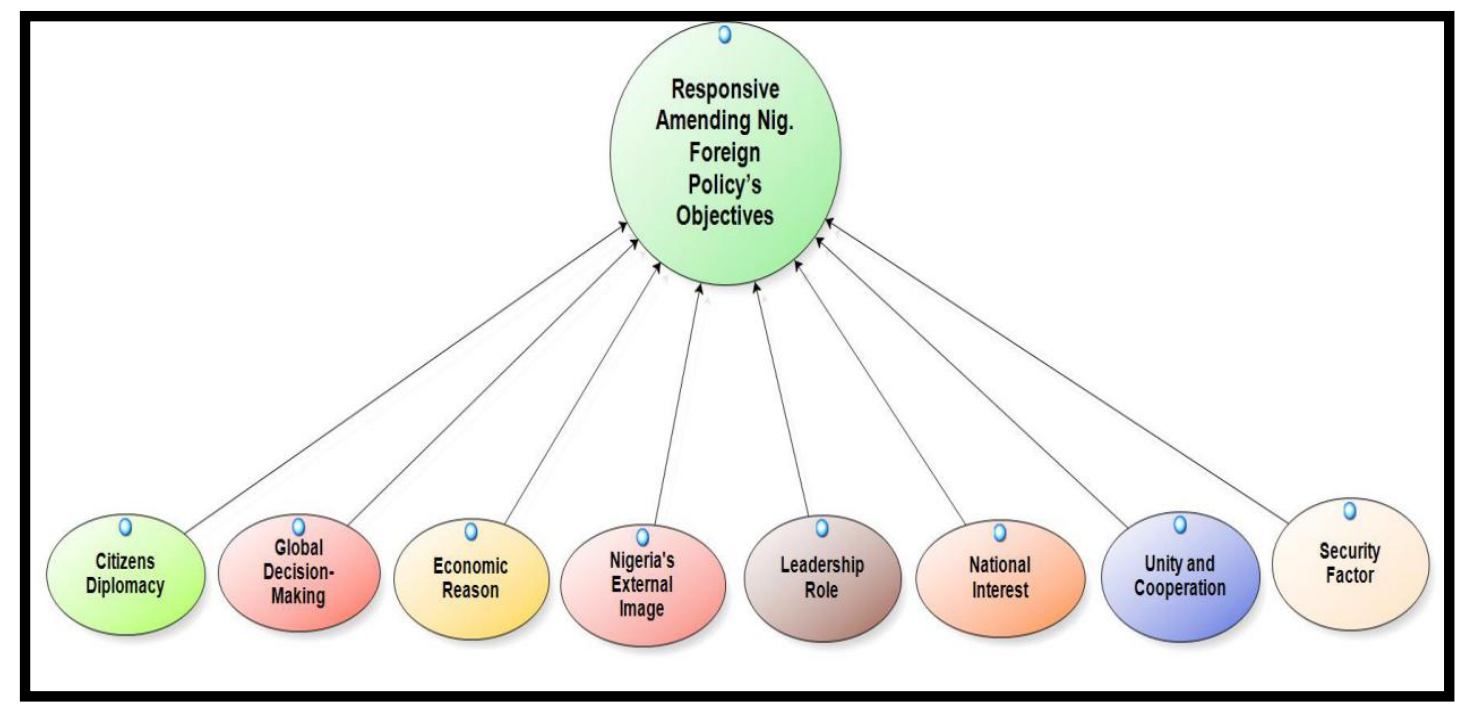

Fig. 1 - Responsive for amending Nigerian foreign policy objectives

\subsection{Leadership Role}

Nigeria's strong leadership role in the African continent provides the impetus behind the adjustment of its foreign policy objectives towards the continent. This policy preference subsequently contributed to the success of the country's goals of transforming the OAU to the AU. According to Oni and Taiwo (2016), Nigeria's positive gesture to other countries, particularly African States has relatively enhanced the country's leadership reputation among African countries. The Nigerian government was fully aware that its close relationship and positive gesture to other States in the continent through its foreign policy practice might increase its chances to have greater influence on the continent. Nigeria has long been known for its strong leadership role in Africa and for some scholars, it should do more to promote and accelerate socio-economic development and growth for the benefit of the entire African continent (Ota, \&Ecoma, 2015; Oni \& Taiwo, 2016).

By shouldering the responsibility of leading its African neighbours towards ensuring the continent becomes a comfortable place to live, Dede (2013) affirmed that such action would fulfil its earlier promises to assist the continent as articulated by its leaders. Furthermore, he added further that the promise made by Nigerian government through its 
Minister of Foreign Affairs, Dr. Jaja Anucha Wachukwu during the $16^{\text {th }}$ session of UNGA in New York on $10^{\text {th }}$ October 1961 that:

We are independent in everything, but neutral in nothing that affects the destiny of Africa. The moment Africa is affected, we are involved. We want to make this absolutely clear, Nigeria finds itself involved in anything affecting the African continent anywhere, in any square inch of the African territory - we are involved....And being a member of the African community and feeling ourselves completely bound to its destiny and accepting our involvement in everything that pertains to it...The peace of Africa is the peace of Nigeria. Its tribulations are our tribulations and we cannot be indifferent to its future (Dede, 2013, pp. 205-206).

One can argue that Nigeria will always give its support to facilitate sustainable economic development and securing stability in the African continent, a strategy it believes provide benefits for the country, particularly in fulfilling its national interest.

Similarly, the above assertion was supported by informant UniAbuja whereby he attached the natural resources endowed to Nigeria as a form blessing that favours African continent. He stressed that:

Nigeria's destiny to lead fellow African countries manifested in all what God has given to us. It is not just for us alone, but am giving it to you to lead other African countries, though if we cannot, it will be selfish to say yes all these resources, solid minerals, the oil, the intellectuals, the population, the agrarian, all these conducive climates, it is just for us Nigerians No! It is for you to assist others in distress too. So, if we are to go by the manifest destiny theory therefore, regardless of what we are going through or the challenges we are facing at home, I think it is incumbent on us to address, to show concern for the plight of our brothers or fellow African nations (Informant UniAbuja, personal communication, September 9, 2017).

In addition, another informant corroborated on what informant UniAbuja has stressed "Nigeria is all around favoured with assortments of human and material assets, so accomplishing more as far as support to the African nations will make it greater and more prominent in the psyche of the nations" (Informant MFA4). This view was equally supported by informant Unilorin that "it is important that Nigeria continues to maintain Africa as its centrepiece policy, to continue to stay engaged and it is important for it to continue to play its role irrespective of whether we have benefitted or not".

Consequently, playing a leading role as Nigeria in the African continent has been relatively easy. This has influenced informant $\mathrm{ABU} 2$ to assert that:

With leadership comes responsibility and we are endowed not only in Oil but other minerals and natural resources, and human resources or human capacity. So, at the same time, I think it is a fair question that should Nigeria now have been too generous and so committed (Informant ABU2, personal communication, September 16, 2017).

Indeed, the reward arising from the generosity of Nigeria to African continent can be both tangible and intangible as argued by informant Unilorin:

It depends on what one defines as benefits because some benefits can be tangible, many benefits may be intangible. Some benefits maybe short term, others may be long term. So, one has to be cautioned in doing the assessment of Nigeria's centerpiece policy so that one does not throw away the baby and the birth-water all together (Informant Unilorin, personal communication, August 28, 2017).

Therefore, it is arguable from the above that Nigeria may not reap or get the rewards of her good deeds to African continent in terms of monetary value, but some rewards or benefits coming into the country in form of intangible cannot be quantified. Hence, it would be of immense advantage for Nigeria to continue its leadership role in the continent. And if there is a need for it to amend its foreign policy objectives, such should be made in a form that will benefit African States more. Fig. 2 below shows a consensus among the interviewees regarding Nigeria's leadership role as a need for amending the country's foreign policy objectives toward Africa. 


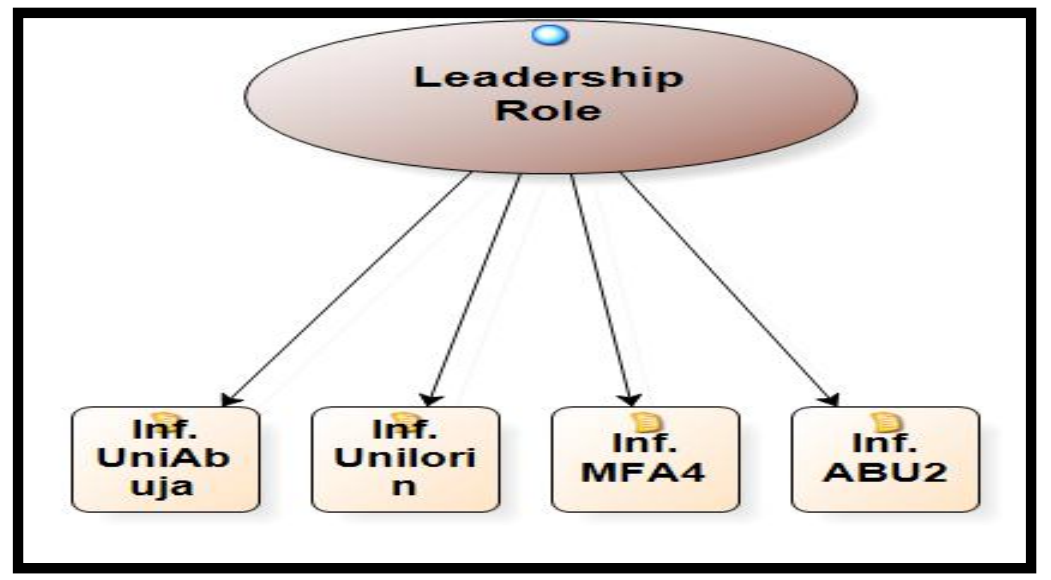

Fig. 2 - Leadership role as a need for amending Nigerian foreign policy's objectives

\subsection{Security Factor}

The priority for Nigeria to continue and be more proactive in ensuring the security and stability in the African continent is perhaps one of the key motivations for her to adjust its foreign policy objective towards the continent. This adjustment has enabled Nigeria to successfully persuade other African countries to carry out the replacement of OAU with AU. If Nigeria failed to play a strong role in ensuring the security well-being of Africa, security issue or instability from the neighbouring States may spill over to the country (Oni \& Taiwo, 2016). Nigeria is aware of the peace dividend that it can acquire from a stable and peaceful Africa. Its good image as a trustworthy partner can equally be boosted not only in Africa but also in the entire world if Nigeria continues its commitment to contribute more towards the continent's security needs. By citing Boko Haram insurgency in Nigeria, as an example, informant ABU2 stressed the importance of the country to be committed in the security of the continent:

Boko Haram is a very threat to Nigeria's security which is one of the fundamental objectives of Foreign policy, which is to secure nation territorial integrity sovereignty. Boko Haram was a serious challenge, we expect that other countries in Africa, particularly the neighbouring countries should work with us because they also becoming a regional menace. So, it is of their interests but it is also a payback time for Nigeria to say, we have been very helpful to others now we have difficulties this is the time for them to (assist) (Informant ABU2, personal communication, September 16, 2017).

The informant stressed that if Nigeria has not been helpful to other countries in Africa, particularly the neighbouring countries such as Benin, Chad, Cameroon and Niger, its domestic fights against Boko Haram will only be a mirage. This same point is what informant NIIA1 corroborated to counter the argument of the antagonist group that was agitating for Nigeria to reduce its involvement in the continental affairs of Africa. The informant posited that:

Nigeria has been sowing here and there and we never get to the roots of what have sowed in other African countries; particularly in the areas of peace and security or peacekeeping so to say in a clear terms, because this things has to do with so much expenses expended on peacekeeping in countries like: Liberia, Sierra Leone, and some other trouble-spots in Africa where Nigeria has intervened....I always beg to differ on this matter of reaping benefits on monetary terms. Safeguard of men's lives, I stand firm on that and in support of that as well (Informant NIIA1, personal communication, October 4, 2017).

The informant further argued that Nigeria must not relent in contributing her quota towards making the continent a peaceful place for Africans. He re-emphasized his claims on the need for Nigeria to do more to Africa, especially in the area of peace and stability that:

Now, with situation that we have witnessed in Rwanda, the genocide of Rwanda when Nigeria was not involved, I know it was not with the ECOWAS territories but assuming we had even intervened in such a situation because it is in Africa, and as a member of African community. Is it possible we could have averted what had happened in Rwanda? Then, a joiner to that, is it possible we could have had a more catastrophic situation if we have done nothing in Liberia and in Sierra Leone. Is it possible? The Liberians and Sierra Leoneans would have hacked themselves to what have happened in Rwanda, is it possible? (Informant NIIA1, personal communication, October 4, 2017).

Hence, with the above view, informant BUK suggested that, "Nigeria should continue to be good to her neighbours because there is good in keeping unity with neighbours, and such can assist you security wise". The assertion has been 
argued by Folami and Naylor (2017) that such assistance has been working for Nigeria particular in addressing the case of Boko Haram and reduction in the crime rates along the country's borders where neighbouring countries like Benin, Chad and Cameroon are jointly fighting the insurgence along the borders.

Moreover, another informant has supported the argument on the need for Nigeria to always render support for African continent security because:

By the time we open our eyes, those crises will have already snowbound into Nigeria and by the time it snowbound into Nigeria, we will not have the time, the patience, the resources to cope with. The earlier we go there and suppress it, the better. So, that you keep it there, do not let it come here. So, it is not by mistake that God has given us our resources the way it was done. It was not mistake that God made the country the most populous in Africa, it was not by mistake that God gave us those arable vast lands with potentialities, with resources, it is not by mistake. God has given us all these endowments for us to take care of other countries, therefore if we have to go by the theory of manifest destiny therefore, that our destiny to lead fellow other African countries manifested in all what God has given to us (Informant UniAbuja, personal communication, September 9, 2017).

There are several advantages for Nigeria pertaining to its timely intervention on the domestic affairs of other countries as part of ensuring peace and security in Africa. It worth noting that Nigeria could indirectly preventing the crisis erupted in its neighbouring countries from spreading into her country, and at the same time building her positive image with its surrounding neighbours. This is what informant NIIA2 described as "you do not build a positive picture of yourself inside" when not assisting others. This particular view was equally shared by informant Unilorin that "If people within your region do not see you in a favourable light, you do not construct a positive image of yourself within your immediate environment; it is not in the interest in your strategic and security interest".

Therefore, Nigeria's contribution to Africa's security need through her foreign policy objective should be further strengthened in order to improve its influence in the continent. Fig. 3 below illustrates a consensus among the interviewees regarding security factor as a need for amending Nigerian foreign policy's objectives toward Africa.

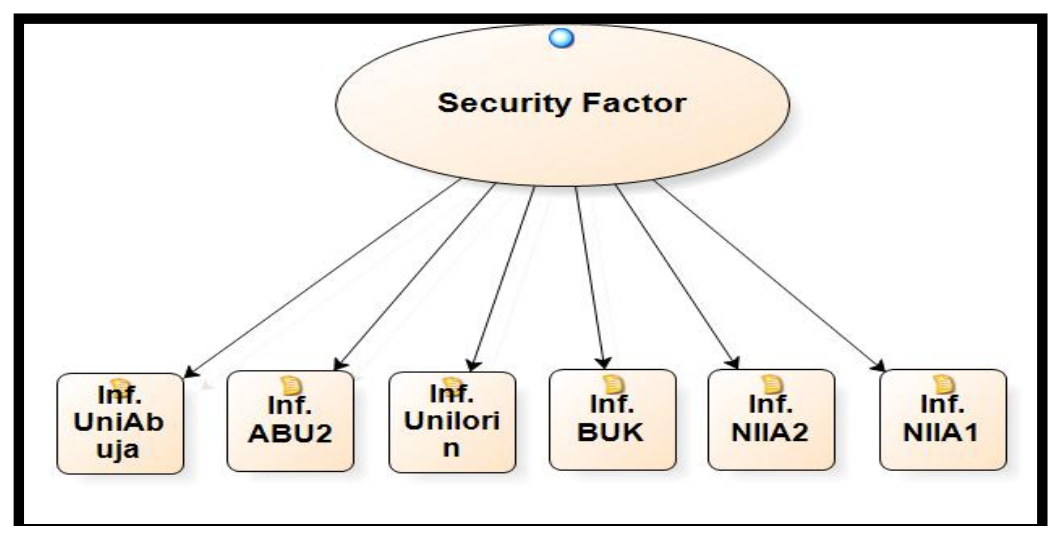

Fig. 3 - Security factor as a need for amending Nigerian foreign policy's objectives

\subsection{Nigeria's External Image}

Nigeria's external image is another important reason why the country should adjust its foreign policy objective towards Africa in order to contribute more to the stability and development of the continent. Nigeria's active contributions towards Africa's stability and development have enhanced its image internationally. This image is one of the factors that determined Nigeria's influence in the international community. This has been elaborated by Ashiru (2014) that:

Nigeria has continued to earn more respect in the international community despite lingering domestic challenges. While we have experienced some security challenges locally, this has not affected the goodwill, friendship and partnerships that Nigeria continues to enjoy in the comity of nations (p.10).

Hence, for Nigeria to be able to achieve her foreign policy objectives, its image and reputation, there is a need for improvement in her inputs towards Africa's development and stability (Fayomi, Chidozie, \& Ajayi, 2015). Such reputable image has been an essential part of what made Nigeria to have more influence in the transformation of the OAU to the AU in comparison to other African States.

The needs to project a good image of country is equally stressed by informant Unilorin who argued that "If people within your region do not see you in a favourable light, you do not construct a positive image of yourself within your 
immediate environment, it is not in the interest in your strategic and security interest". His argument was equally buttressed by another informant that "if you do not build a positive picture of yourself inside your quick condition, it is not to the advantage of your security" (Informant NIIA2). It can be summed up that the two views emphasized on the impact of building a good image of a country to its national security. Meaning that if people around you did not benefit from your good gestures there is every tendency for security lapses in such country (Taylor, 2015).

Furthermore, an Informant has attributed assisting neighbouring countries to international recognition. He argued that "doing this favours to Africa, Nigeria is indirectly promoting her international recognition or image" (Informant BUK). And gaining international recognition on Nigeria's part will improve the country's influence in the global decision making to favour Africa more at the international level. This indirectly, will have achieved part of Nigerian foreign policy objectives.

However, if Nigeria proved otherwise as argued by Informant ABU1 that "if you say Nigeria first, it will affect not only the country's external image but also its citizens living outside". Hence, it will be in the interest of Nigeria to always favour African continent more if there should be amendment in her foreign policy objectives towards the continent. Nigerian foreign policy principles designed by the country's leaders was to foster unity and cooperation more in the continent in order to ensure stability and at the same time, to accelerate the development in Africa. Therefore, Fig. 4 below shows a consensus among the interviewees regarding Nigeria's external image as a need for amending the foreign policy's objectives of Nigeria towards Africa.

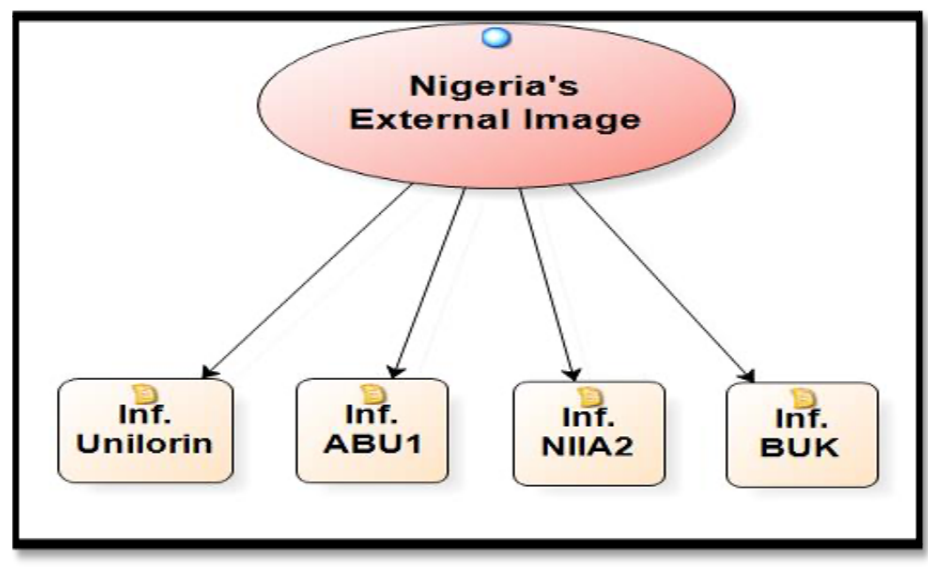

Fig. 4 - External image as a need for amending Nigerian foreign policy's objectives

\subsection{Global Decision-Making}

Similarly, the projection of good or positive image of Nigeria externally, as argued by Akinsanya (2014), has influenced positively on its both the regional, continental and global decision making. There is a need for Nigeria to amend her foreign policy objectives towards favouring Africa in order to promote its influence in the decision-making process at international level. A notable example of this could be seen from Nigeria's influence during the AU $19^{\text {th }}$ Ordinary Session in Ethiopia between July $15^{\text {th }}$ and $16^{\text {th }} 2012$ when the AU wanted to appoint the Commission's Chair. Nigeria was against the South African candidate, Nkosazana Dlamini-Zuma but preferred a candidate from Gabon, Jean Ping. However, due to Nigeria's influence in African continent, other African countries who are equally member of AU supported Nigeria and voted for Mr. Jean Ping as the Chair of AU Commission (Wapmuk, 2014). This is arguably one of the advantages of the need for a country to favour more one's continent or neighbours, in order for it to have influence when it comes to decision- making process.

Furthermore, Nigeria's Afro-centric policy has arguably enabled the country to have relatively considerable influence in determining the final outcome of decision making process in Africa when compare to other countries in the continent. Akinsanya (2014) is of the view that "at the policy level, Nigeria, in the chair of African Union from 20042006 under President Olusegun Obasanjo greatly influenced policy decisions in the AU...working in close partnership with...Ethiopia, Mali, Algeria and South Africa" (p.107). This has been made possible due to Nigeria's previous record of generosity to the African continent. An informant equally buttressed this argument by saying, "good hands of Nigeria to other countries will foster unity and cooperation which the country can use to influence its decisions at both regional, continental and global level"' (Informant BUK).

Similarly, informant MFA1 was of the opinion that if Nigeria will amend its foreign policy objectives towards Africa "it is even better for Nigeria to do more if it can, in order to add more weight to Nigeria during any regional or continental decision making" (Informant MFA1). His view was further corroborated by another informant that: 
Nigeria should not reduce its relationship and foreign policy gesture to the African continent. If at all that Nigeria wanted to amend its foreign policy, it should be positive, in the sense that the country will be able to do more than what it has been doing to the continent. It is true that Nigeria is well blessed with varieties of human and material resources, so doing more in terms of favour to the African countries will make it bigger and greater in the mind of the countries. So, in my own opinion I think Nigeria should do more, contributing more to the affairs of its fellow African countries (Informant MFA2, personal communication, September 8, 2017).

The positive impacts of Nigeria's favourable policy of assisting African continent through her foreign policy objectives have numerous advantages to the country. This was equally stressed by informants MFA3 and MFA 4 respectively that it is "better for Nigeria to accomplish progressively" and "be more prominent in the psyche of the (African) nations". By doing this, Nigeria will promote unity and cooperation between and among African States. Fig. 5 below indicates a consensus among the interviewees regarding global decision-making as a need for amending Nigerian foreign policy's objectives toward Africa.

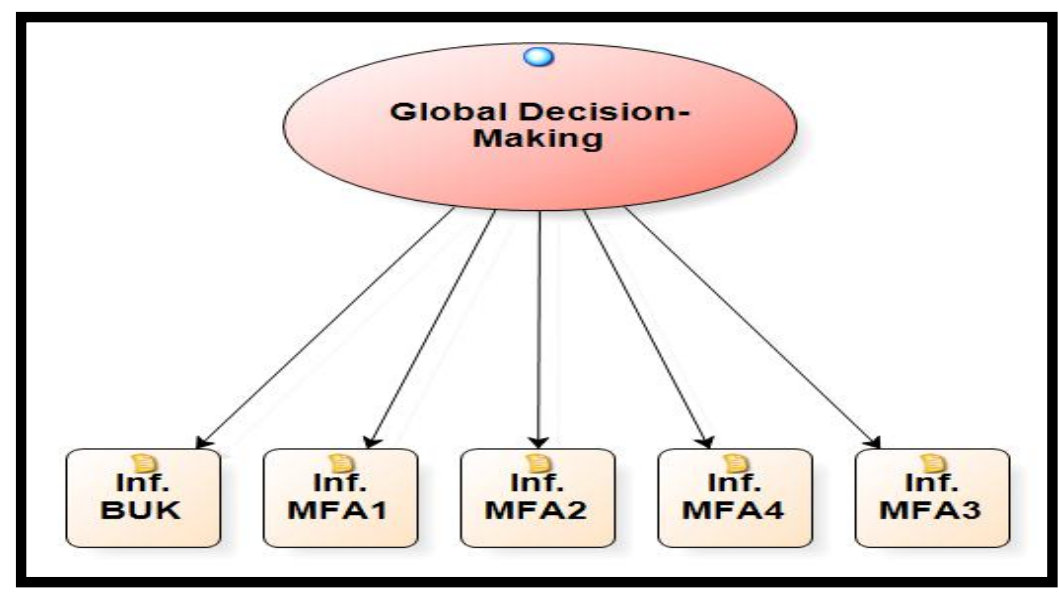

Fig. 5 - Global decision-making as a need for amending Nigerian foreign policy's objectives

\subsection{Unity and Cooperation}

Fostering unity and cooperation in Africa underpins one of the reasons why Nigeria has adjusted her external policy to prioritising the well-being of African continent. According to Ota and Ecoma (2015), Nigerian foreign policy was designed to foster unity and cooperation among African States. This policy goal has substantially influenced Nigeria's role in Africa, including her active participation throughout the process of transforming the OAU to the AU.

Moreover, the advantage of maintaining unity and cooperation among Nigeria's neighbouring States was recognized by informant MFA1 when he argued that:

Nigeria should continue to make friends and if possible to add friend together with the old friends. Your house is said to be secured only if you are generous to your neighbours, and one of the ways you can be generous to your neighbours is to always come to them during their needs in order for them to reciprocate such during yours (Informant MFA1, personal communication, September 8, 2017).

In friendship, there is always cooperation which can bring unity and development to an area. He stressed further that:

Nigeria should continue to do more to its neighbouring countries and the entire Africa at large, because it is when you have contributed to others affairs that they can count on you, and for them to have counted on you, you are indirectly having input or influence or control in their affairs (Informant MFA1, personal communication, September 8, 2017).

This view was supported by informant MFA2 that "Nigeria is well blessed with varieties of human and material resources, so doing more in terms of favour to the African countries will make it bigger and greater in the mind of the countries". Hence, there will be cooperation when countries are good to one another as observed by informant MFA3 that, "one of the ways you can be liberal to your neighbours is to dependably come to them amid their requirements".

Similarly, informant BUK has argued in supports of the views above that, "good hands of Nigeria to other countries will foster unity and cooperation which the country can use to influence the decisions". As Nigeria is favouring African 
continent through her Afro-centric policy, she will be expecting payback time from her beneficiaries as argued by an Informant that:

Those countries, where we have spent a lot of energy, our lots of political capital you know, money and materials, it is fair to begin to expect that at least. This will translate into some influence in those countries and they will be more favourably disposed towards cooperating with Nigeria in the economic role (Informant ABU2, personal communication, September 16, 2017).

The fear of needy time when Nigeria will be eager to see other countries coming to its supports either in terms of influence or decision making, has also canvassed for the country to maximize its favours to other countries. This view was further stressed by informant NIIA2 that "its (Nigeria) centrepiece arrangement to keep on staying drew in and it is vital for Nigeria to keep on playing its part regardless of whether we have profited or not". Hence, the theory of manifest destiny as posited by informant UniAbuja that:

It is for you to assist others in distress too. So, if we are to go by the manifest destiny theory therefore, regardless of what we are going through or the challenges we are facing at home, it is incumbent on us to address, to show concern for the plight of our brothers or fellow African nations (Informant UniAbuja, personal communication, September 9, 2017).

On the other hand, informant MFA4 has enjoined Nigeria to "accomplish all the more, contributing more to the undertakings of its kindred African nations". This will promote unity and indirectly make the African States to cooperate with one another. Another informant has condemned weighing Nigeria's contribution to Africa in cost benefit analysis where he stressed that:

If you look at the foreign policy on the basis of cost benefit analysis you will get it wrong especially when it comes to relating with your neighbours or relating with your region and if you are assisting other African countries because you are more endowed than others that is a natural course of action. While you are not under any other obligation to do it, it is strategically important that you do it, because if you did not do it, during your time of needs nobody will rise up for you (Informant Unilorin, personal communication, August 28, 2017).

The view above was supported by informant NIIA1. Rather than using cost benefit approach to measure Nigeria's contributions outside, it will be advantageous to "put it side by side, the amount of money been stolen by the kleptocratic class in Nigeria vis-à-vis what went out to peacekeeping", one will then conclude that it is better for the country to continue its good gesture to its neighbours. This is because Nigeria's inputs towards the development in African continent will bring unity and cooperation among African States. Fig. 6 below illustrates a consensus among the interviewees regarding fostering unity and cooperation as a need for amending Nigerian foreign policy's objectives toward Africa.

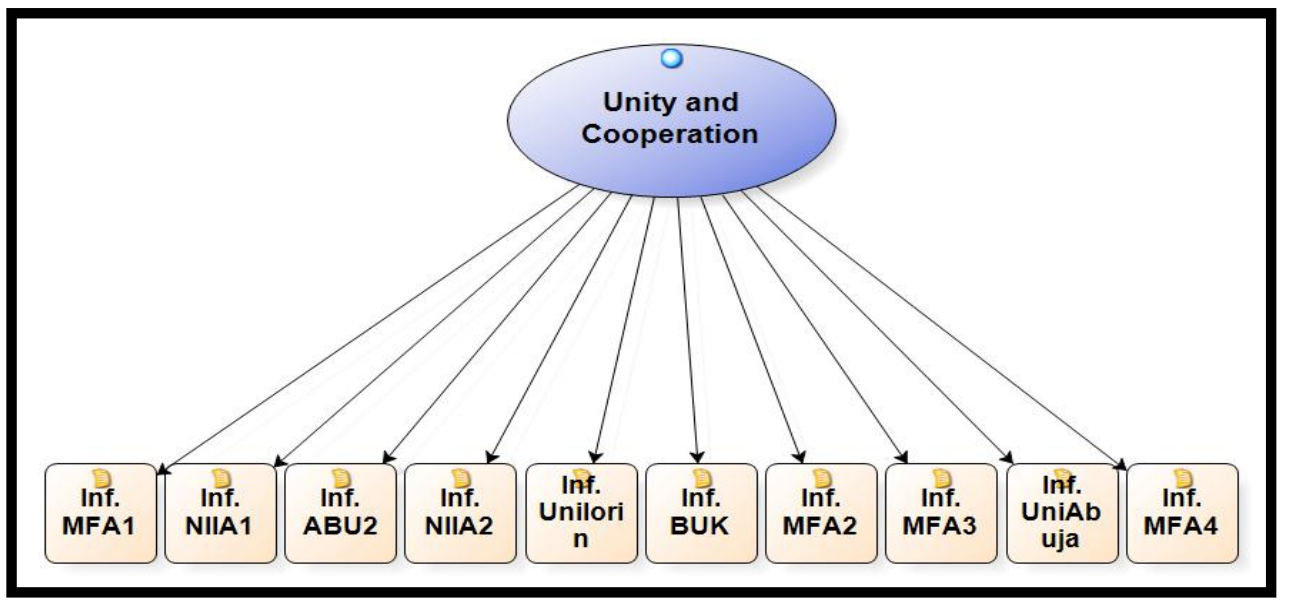

\subsection{Citizen Diplomacy}

Fig. 6 - Unity and cooperation as a need for amending Nigerian foreign policy's objectives

The citizen diplomacy is another reason for Nigeria to improve more on her foreign policy in order to benefit the country's nationals living in another country. As argued by Adams and Ebegbulem (2016), and Usman and Obiyan (2017), Nigerian foreign policy principles in one the key factors responsible for the good treatment and respect received by its citizens living outside the country. If Nigeria's policy and relationship towards other countries are good, its nationals living in those countries will enjoy positive gesture in their countries of residence and vice versa. This has 
become imperative for Nigeria to always prefer the African continent more if she is to amend her foreign policy objective for the benefits of its citizens living in other countries.

Similarly, an informant has argued in support of the view above that Nigeria should always consider her population which made Nigerians to be found everywhere in the world. He posited that:

We have the biggest population by far, in fact it is said that by the year 2050, it seems to be a long time from now but it is not, that in the life of a nation, that Nigeria will be the third most populous country in the world after China and India (Informant ABU2, personal communication, September 16, 2017).

With Nigeria's population rate, it may not sound meaningful for the country to pursue a policy of the country first alone, rather than African first as argued by informant ABU1. He stressed that:

Nigeria first may not necessarily help the country because if you want to talk about citizen diplomacy, there is no African countries where we do not have Nigerians, so if you say Nigeria first, it will affect not only Nigeria's external image but also Nigeria citizens living in other African States (Informant ABU1, personal communication, September 11, 2017).

In fact, the need to foster more cooperation among African States and for the benefits of its citizens residing in other countries has canvassed for "Nigeria's initiative for Diplomatic passports for all African citizens...to promote cooperation, integration and foster development in the continent" (Informant MFA1).

Moreover, another Informant has argued that "doing more favour to Africa, Nigeria is also doing herself good because its citizens living in other countries too will enjoy the benefit of what the country is doing outside" (Informant BUK). The need for Nigeria to maintain good relationship with other countries is equally emphasized by Informant UniJos that, "Nigeria should keep on maintaining its fellowship" in order to promote brotherliness. Informant MFA4 further enjoined Nigeria to "encourage improvement/development in the continent (African continent)" in order to make the entire Africa benefit from its natural potentials.

Therefore, it is arguable from the above that Nigeria's influence in African continent will be maximized if the country adjusts positively its foreign policy towards Africa. It will be at Nigeria's benefit to maintain good relationship with other countries in order to protect its citizens' rights and freedoms living outside the country. Hence, Fig. 7 below shows a consensus among the interviewees regarding citizens diplomacy as a need for amending Nigerian foreign policy's objectives towards Africa.

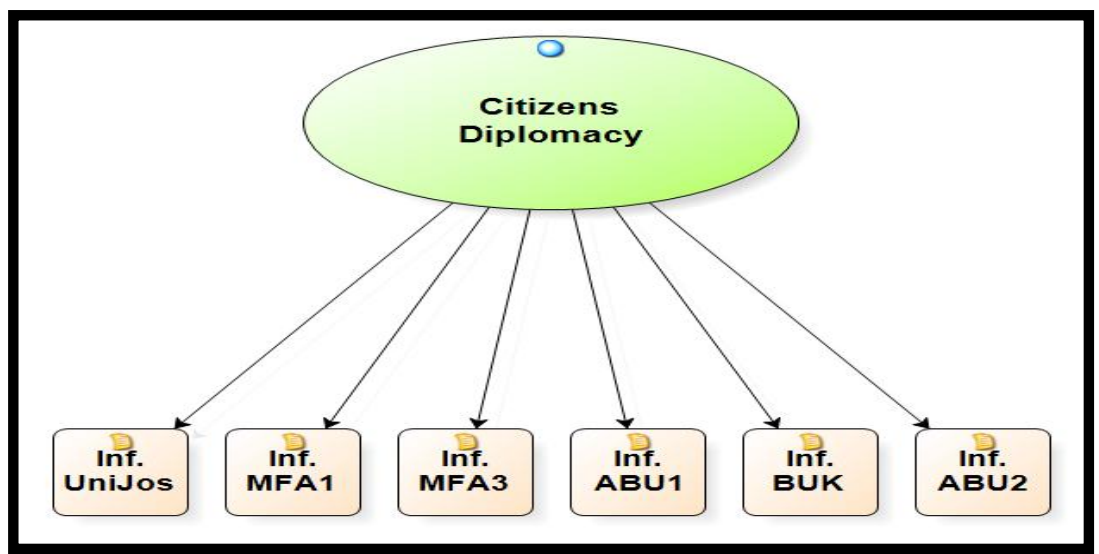

Fig. 7 - Citizens diplomacy as a need for amending Nigerian foreign policy's objectives

\subsection{National Interest}

Nigeria's national interest, which forms an integral part of its foreign policy posture and orientation, is another influencer in shaping the country's role towards transforming the OAU to AU. This influence was made through its Afrocentric policy as part of Nigerian foreign policy objectives towards Africa and at the same time the protection of her national interest through cooperation and cordial relationship with African countries (Ajayi, Njoaguani, Olorunyomi, \& Folarin, 2015; Adams \& Ebegbulem, 2016). Nigeria's National Interest should be protected at all time, so also the need for the country to always arrive to the rescue of Africa as part of the pledge made by its leaders to Africa.

Furthermore, Nigeria's commitment to Africa has been described by informant ABU1 as "a matter of self-interest for Nigeria to be pushing for African unity". This self-interest of Nigeria will allow for realization of the country's national interest as argued by another informant that: 
If Nigeria is to amend its foreign policy, it should be on positive side, meaning that Nigeria should do more of what she has been doing to the continent. This is needed due to several factors. One of such is the issue of national interest. Nigeria needs to protect her national interest with Africa (Informant BUK, personal communication, August 26, 2017).

Similarly, informant MFA1 also supported the views that Nigeria needs to maintain cordial relationship with other countries for its national interest to be achieved. He stressed that "Nigeria should continue to maintain its brotherhood position or big brother role played in Africa not because of the immediate benefits but for a long-term advantage which will be needed by the country in future".

Moreover, informant Unilorin, has equally observed that it will be in Nigeria's interest to support African continent more rather than withdrawing or reducing its favouring gesture to the continent through its foreign policy. He argued that:

The tendency will be for you to withdraw and reduce the assistance or supports that you are given to the African countries when you realize that the cost at which benefit, or the benefit does not conform with the cost or less than the cost, the tendency is for you to scale-down in your things. But remember that once you scale-down you create space for other interest to come-in that may not necessary be the interest of Nigeria (Informant Unilorin, personal communication, August 28, 2017).

Therefore, for Nigeria's national interest to be achieved adequately, the country needs to contribute more to the development of African continent through its foreign policy. This will improve its influence and at the same time promote cooperation among African States. Fig. 8 below illustrates a consensus among the interviewees regarding national interest as a need for amending Nigerian foreign policy objectives toward Africa.

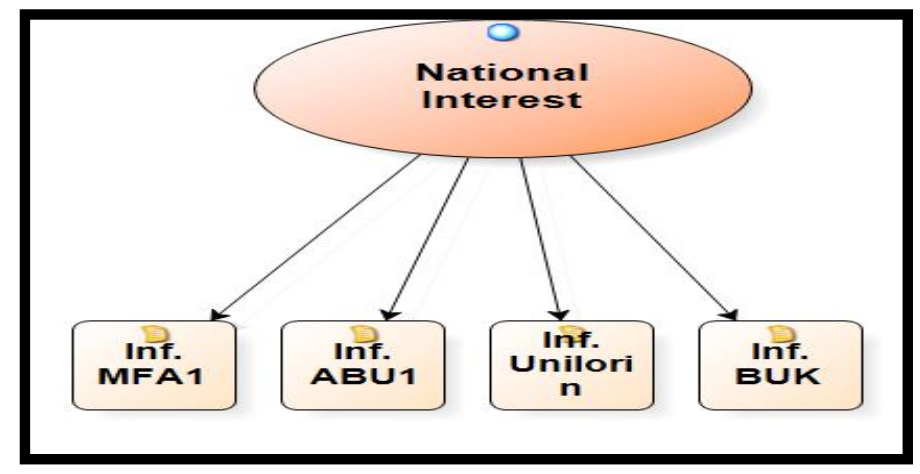

Fig. 8 - National interest as a need for amending Nigerian foreign policy's objectives

\subsection{Economic Reason}

As part of achieving Nigeria's national interest, the country's economic potentiality is another reason why the country should favour the African continent more in her foreign policy objectives, a policy orientation that has enabled the country to successfully transformed OAU to AU. The abundance and myriad natural resources possessed by Nigeria makes the country to be reckoned with not only by the African countries, but also the entire world (Bunwaree, 2008; Yoo, 2016). Consequently, Nigeria is in a position to do more to Africa while at the same time, conscious of the need to explore and establish a functional market for the country's manufactured goods and natural resources. As agreed by informant ABU1, "it is in our self-interest economically and diplomatically that Africa will be a major market for Nigeria output". This position was equally supported by informant UniJos that "it is to our greatest advantage financially and strategically" if a functional market is organise in Africa in order to promote Nigeria's economy. Informant ABU2 equally added that "well, we have very little choice, we are parts of Africa, we are a leader in Africa, and leadership implies being proactive in addressing the issues. We are supposed to be the largest economy". It can be said that, it is in the interest of Nigeria's buoyant economy for the country to consider African continent as a suitable market for its products.

In addition to above reasons for Nigeria to adjust in its foreign policy objectives to favour African continent more, informant BUK posited that "Nigeria should continue to be good to her neighbours because there is good in keeping unity with your neighbour and such will assist your security wise and economic wise as well". Conversely, informant NIIA1 faulted the justification of antagonist group on the need for Nigeria to expend the resources utilized outside the country for Nigeria's development. He argued that:

Is it the resources that we takeout that we do not have functional industries, that could actually take advantage in form of foreign direct investments, when we now go to create conducive atmosphere that investors can now go in, or is it their fault that we do not have those investors to go in (Informant NIIA1, personal communication, October 4, 2017). 
Consequently, informant NIIA1 view on the antagonist group perception on Nigerian foreign policy objectives favouring Nigeria was supported by Informant UniAbuja that "is it the money spent by Nigeria on other countries that made Nigeria to be facing some challenges at home, (such as) economic challenges, today we are in recession" (Informant UniAbuja).

Therefore, the economic challenges and other financial difficulties that Nigeria might be experiencing should not attach to its foreign policy preference to assist African countries. Hence, it is arguable from the above that it is in the interest of Nigeria to always favour African continent in order to create markets enabling for its products. Fig. 9 below indicates a consensus among the interviewees regarding economic reasons as a need for amending Nigerian foreign policy's objectives toward Africa.

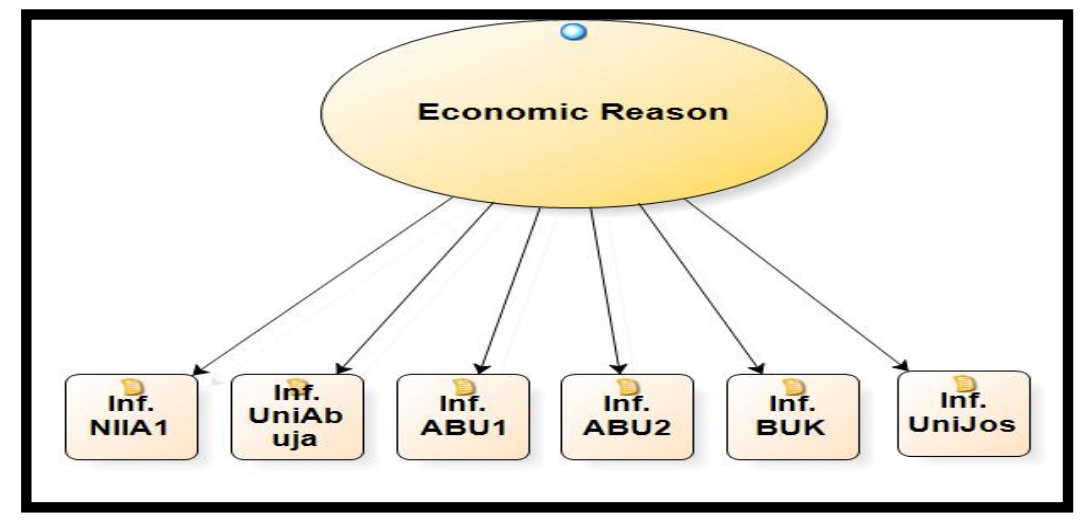

Fig. 9 - Economic reason as a need for amending Nigerian foreign policy's objectives

\section{Conclusion}

This paper examines issues surrounding the too generous and committed nature of Nigerian foreign policy objective where most of her beneficiaries refuse to appreciate the kind gesture received from the country. There are two ideological views on Nigeria's contribution and preference on the well-being of African countries. The first group was of the opinion that Nigeria should reduce its contribution and good gestures to other African countries in order to cater more for its domestic needs. On the other hand, the protagonist group believe that if there is a need for Nigeria to amend or adjust its foreign policy objectives towards Africa, it should be more favourable to African continent. Hence, a number of reasons have been advanced from this study's analysis regarding the need for Nigeria to strongly favour African continent more in its foreign policy objectives. These motives include leadership role, security factor, economic reason, its image, global decision-making, citizen diplomacy, and national interest. Having examined the likely pros and cons that might be metedout on Nigeria and her citizens, one will be convinced to agree that the more favourable Nigerian foreign policy is to Africa, the better for the country and vice versa.

\section{Acknowledgement}

The authors would like to acknowledge Universiti Utara Malaysia (UUM) for the support of the study particularly during the field survey.

\section{References}

Adams J.A. \&Ebegbulem, J.C. (2016). Nigeria's National Interest and Interventions in West African Conflicts. African Journal of Politics and Administrative Studies. 9(1), pp. 70-84

Adebajo, A. (2008). Hegemony on a Shoestring: Nigeria's Post-Cold War Foreign Policy.In Adebajo, A. and Mustapha, A.R. (eds.), Gulliver's Troubles: Nigeria's Foreign Policy after the Cold War, (pp. 1-37). Pietermaritzburg: University of KwaZulu-Natal Press

Ajayi, L., Njoaguani, T., Olorunyomi, B. \& Folarin, S. (2015). Nigeria's Foreign Policy and Codification of National Interest: A Prescriptive Analysis. Covenant University Journal of Politics and International Affairs (CUJPIA). 3(2), pp. 68-81 
Akinsanya, O. (2014). Nigeria's Role in the Transformation of the OAU to AU. In Akinterinwa B.A (ed). Organisation of African Unity/African Union at 50: Nigeria and the Quest for African Unity and Renaissance, Volume Two, (pp. 97112). Nigerian Institute of International Affairs Press, Lagos, Nigeria

Ashiru O. (2014). Nigeria's Foreign Policy: New Realities in a Changing World. In Akinterinwa B.A (ed). Organisation of African Unity/African Union at 50: Nigeria and the Quest for African Unity and Renaissance, Volume Two, (pp. 115). Nigerian Institute of International Affairs Press, Lagos, Nigeria

Bunwaree, S. (2008). NEPAD and Its Discontents.In John Akokpari, Angela Ndinga-Muvumba and Tim Murithi (eds), The African Union and Its Institutions. Aukland Park: Fanele

Dauda, M. \& Ameen, L. (2017). Nigeria's Quest for a United Nations Security Council Permanent Seat: Prospects and Constraints. Asian Journal of Research in Social Sciences and Humanities. 7(2), pp. 826-841

Dede, B.N. (2013). Nigeria in Africa Institutions: ECOWAS, AU, ADB, etc. In Anyaoku, E. (ed). Review of Nigeria's Foreign Policy: Issues and Perspectives (pp. 200-217). Lagos: Nigeria’s Institute of International Affairs

Fayomi O.O., Chidozie F. \& Ayo, C. K. (2015). A Retrospective Study of the effects of Xenophobia on South AfricaNigeria Relations. In: World Academy of Science, Engineering and Technology, May, Tokyo, Japan

Folami, O. M., \& Naylor, R. J. (2017). Police and cross-border crime in an era of globalisation: The case of the BeninNigeria border. Security Journal. 30(3), pp. 859-879

Folarin F.S. (2013). Nigeria and the Dilemma of Global Relevance: Foreign Policy Under Military Dictatorship (19931999). Covenant University Journal of Politics and International Affairs (CUJPIA), 1(1), pp. 21-47

Folarin F.S. (2013). Nigeria and the Dilemma of Global Relevance: Foreign Policy Under Military Dictatorship (19931999). Covenant University Journal of Politics and International Affairs (CUJPIA), 1(1), pp. 21-47

Gambari, I.A. (1989). Theory and Reality in Foreign Policy Making: Nigeria After the Second Republic, New Jersey: Humanities Press International

Gambari, I.A. (2017). Nigeria: Democray, Development and Foreign Policy. A Memorial Lecture in Honour of Late Professor AbdulRaufu Mustapha on 26 ${ }^{\text {th }}$ August, at Musa Yar'adua Centre, Abuja, Nigeria. (Unpublished)

Levy, J.S. (2013). Psychology and Foreign Policy Decision-Making. In Huddy, L., Sears, D.O. and Levy, J.S. (eds). The Oxford Handbook of Political Psychology, (2 ${ }^{\text {nd }}$ ed.), (pp. 1-33). Oxford University Press

Newman, B. M., \& Newman, P. R. (1995). Development through Life: A Psychosocial Approach (6th ed.). New York, NY: Brooks/Cole Publishing Company

Oni, E.O. \& Taiwo, A.M. (2016). Re-Thinking Nigeria's Foreign Policy Beyond "Big Brotherism Towards Economic Diplomacy. Canadian Journal of Social Science. 12(10), pp. 62-71

Ota, E.N. \&Ecoma C.S. (2015). Nigerian Foreign Policy in a Globalising World: The Imperative of a Paradigm Shift. Journal of Asian Development. 1(1), pp. 55-65

Taylor, I. (2015). Africa in the New World Order: Peace and Security Challenges in the Twenty-First Century. United States: Rowman and Littlefield Publisher

Usman, S.A. \&Obiyan, A.S. (2017). Between Afrocentric Foreign Policy Thrust and Domestic National Security Interest: A Review of Nigeria's Intervention in Mali. Accessed on $15^{\text {th }}$ February, 2018 - https://ssrn.com/abstract=2967481

Wang, L., \& Zhang, Y. (2016). An extended version of the theory of planned behaviour: the role of self-efficacy and past behaviour in predicting the physical activity of Chinese adolescents. Journal of sports sciences, 34(7), 587-597

Wapmuk, S. (2014). Nigeria and the Establishment of the OAU and its Transformation to the AU. In Akinterinwa B.A. (ed.). Organisation of African Unity / African Union at 50: Nigeria and the Quest for African Unity and Renaissance, Volume Two (pp. 53-96). Nigerian Institute of International Affairs, Lagos 
Yoo, H. (2016). Governmental Intervention and Manufacture Industrial Policies in Mineral Rich Sub-Saharan Africa: Focused on Botswana and Nigeria. ADI Colloquium: Development Issues and Challenges in Africa. Accessed on 25 November, 2017 - https://s-space.snu.ac.kr/bitstream/10371/98618/1/제 4 회\%20 콜로키움(유혜림).pdf 